\title{
KATARZYNA BARSKA*
}

\section{ONTOLOGIA ROMANA INGARDENA \\ WOBEC SPORU O UNIWERSALIA \\ W ZWIĄZKU Z KSIĄŻKĄ PAWŁA ROJKA TROPY I UNIWERSALIA}

\begin{abstract}
INGARDEN'S ONTOLOGY AND THE PROBLEM OF UNIVERSALS: IN CONNECTION WITH PAWEE ROJEK'S BOOK TROPES AND UNIVERSALS

This article is an attempt to defend two unfashionable positions in contemporary philosophy: Platonic realism and Ingarden's rich ontology. This defense is in part prompted by the publication of Paweł Rojek's book Tropy i Uniwersalia. Badania ontologiczne (Tropes and Universals: Ontological Investigations), in which the author maintains that both Platonic realism and Ingarden's transcendental realism can be considered as a hidden nominalism. However, this statement: a) is based on a specific interpretation of Platonism, b) narrows down the understanding of universals to only one sense of the term, c) involves misconceptions which are the result of the misinterpretation of Ingarden's ontology - for instance, it is hypothesized that Ingarden's main problem with the concept of universals is extreme separateness of properties from qualities (Ingarden's ideal qualities may be interpreted as universals), d) takes a narrow view of the concept of participation, where the part-whole relationship is almost physical in character.

This paper attempts to show: a) that Plato's and Ingarden's theory of ideas (Forms) may also be open to other interpretations, b) that the assumption that universals are "one in many," would make it difficult for anyone to be called a realist, or become a realist (there have been concerns as to whether all kinds of immanent realism correspond to the proposed definition), c) what is the source of various interpretations of participation, d) that arguments for the transcendence of universals are well-founded.
\end{abstract}

Keywords: universals, ontology, Roman Ingarden, Plato, properties, qualities, ideas, Forms, participation, transcendence

\footnotetext{
*E-mail: barska.katarzyna@gmail.com, ORCID: https://orcid.org/0000-0003-1018-4790.
} 
A to by było nie tyle, co skorupkę odwrócić, tylko jakieś odwrócenie się duszy od dnia, który noc przypomina, ku tej drodze pod górę, istotnie do prawdziwego bytu wiodącej, którą my filozofią prawdziwą nazywamy.

Platon, Państwo, 521c

Artykuł zakłada znajomość ontologii Romana Ingardena, zwłaszcza w zakresie ontologii egzystencjalnej, jako że prezentowane w nim uzasadnienia i argumentacje opierają się nie tylko na twierdzeniach tej ontologii, lecz także na próbach jej dalszego rozwijania. Ponadto w ramach jednego artykułu nie jest możliwe zreferowanie wszystkich rozstrzygnięć Ingardena istotnych dla podnoszonej problematyki ontologicznej. W szczególności mam na myśli całościową analizę momentów bytowych, a także rzetelną eksplikację pojęcia konkretyzacji. Oczywiście najważniejsze określenia i definicje zostały krótko objaśnione.

Należy uprzedzić, że zasygnalizowany w tytule problem jest nadzwyczaj skomplikowany, a jego wyczerpujące omówienie zależy od zaprezentowania tak wielu różnych sposobów podejścia do sporu o uniwersalia, angażujących przy tym niezwykle niejednolitą terminologię, że skoncentruję się jedynie na zarysowaniu moim zdaniem najbardziej interesujących kwestii, które pojawiają się w związku z tą problematyką, oraz ograniczę się do określonej grupy stanowisk.

Podejmuję się więc zadania polegającego na zestawieniu, a nawet skonfrontowaniu pewnych wybranych - zdaniem niektórych badaczy zasadniczych - stanowisk w sporze o uniwersalia z ontologią Romana Ingardena ${ }^{1}$.

W moim przekonaniu wykorzystanie bogatej ontologii Ingardena jest poznawczo owocne i dowodzi jej siły heurystycznej. Dzieje się tak między innymi właśnie dlatego, że jest to niezwykle złożona i bogata wizja ontologiczna. Ingardenowska ontologia staje się narzędziem, które, z jednej strony, pozwala odsłaniać i precyzować trudności piętrzące się wokół problematyki uniwersaliów - dzięki różnorodności kategorii, jakimi dysponuje, i wielopoziomowości egzystencjalnych charakterystyk. Przedstawię te elementy, które wydają się dla sporu o uniwersalia fundamentalne. $\mathrm{Z}$ drugiej strony, ontologia ta pozwala zdemaskować pewne pozorne aporie, nietrafne zarzuty, nieadekwatne interpretacje, dotyczące głównie stanowiska skrajnego realizmu pojęciowego (realizmu platońskiego, realizmu transcendentnego). Przyjmuję zarazem hipotezę, że jest to stanowisko najbliższe Ingardenowi. Towarzyszy mi więc intencja

\footnotetext{
${ }^{1}$ Będę odnosić się do rekonstrukcji trzech pojęć uniwersaliów zaprezentowanej przez Rojka (2008: 45-61), dodając komentarze do tez na temat stanowiska Ingardena, które Rojek stawia w wydanej w 2019 roku książce Tropy i uniwersalia. Badania ontologiczne.
} 
obrony słuszności dwóch współcześnie bardzo niepopularnych i niemodnych $\mathrm{w}$ filozofii koncepcji - skrajnego realizmu pojęciowego i bogatej ontologii.

Zamierzam pokazać, że wszelkie redukcje - jakości do własności (Chrudzimski 2010: 63-64), przedmiotów idealnych (idei) do bytów intencjonalnych (Rojek), uniwersale do własności ${ }^{2}$, idei do własności (analitycy), ogólności do idealności lub jedności (a również do tego, co „faktycznie” wspólne), bytów posiadających egzemplifikacje do ich własnych egzemplifikacji (naturaliści) - mają poważne, często niewystarczająco uświadomione konsekwencje ontologiczne. Ponadto nierzadko u podłoża tego typu redukcjonizmów stoją, niewyrażone expressis verbis, całkiem określone założenia natury metafizycznej3.

Niejednokrotnie spotykana tęsknota za matematyczną prostotą, elegancją i zwięzłością teorii filozoficznych przybiera, w moim przekonaniu, postać kultu cargo. Nie znaczy to jednak, by należało negować dążenia do jasnego, prostego czy oszczędnego formułowania teorii filozoficznych. Niemniej oszczędność i prostota nie mogą być naczelnym kryterium decydującym o wartości teorii - szczególnie w przypadku, gdy ontologię traktuje się jako przygotowanie do metafizyki, czyli aprioryczną analizę związków koniecznych (ustalanie związków wspólistnienia, ale i wykluczania) oraz czystych możliwości $\mathrm{w}$ zawartościach idei wszelakich bytów, a nie tylko bytów realnie istniejących. Jestem przy tym daleka od wygłaszania ocen dotyczących właściwego lub niewłaściwego stawiania problemu uniwersaliów. Zależy mi jedynie na tym, aby pokazać, w jaki sposób pewne sformułowania zagadnienia zawężają zakres możliwych rozwiązań.

\footnotetext{
${ }^{2}$ Takie podejście dominuje w filozofii analitycznej, na co zwraca uwagę również Marek Piwowarczyk (2014: 111): „W związku z tym dla większości filozofów analitycznych problem własności i kwestia uniwersaliów są jednym i tym samym zagadnieniem. Dlatego też znaczna część artykułów na temat własności, w tym np. hasło Properties w Stanford Encyclopedia of Philosophy (Orilia, Paolini Paoletti 2020) i klasyczny już artykuł Alexa Olivera (1996) The Metaphysics of Properties dotyczą problemu uniwersaliów. W takiej sytuacji dość łatwo dochodzi do utożsamienia własności z uniwersaliami”.

3 Wartym odnotowania jest fakt, że współcześni nominaliści zaprzeczają istnieniu własności w ogóle. W tej perspektywie nawet teoria tropów nie jest nominalizmem, a tylko partykularyzmem. Zdumiewa, że mimo osłabionej tendencji redukcjonistycznej i przyjęcia istnienia indywidualnych własności, nadal uznaje się oszczędność teorii tropów za jej mocną stronę: „Tropes provide an elegant and economical base for ontology” (Campbell, Franklin, Ehring 2019: punkt 4).
} 


\title{
1. INGARDENOWSKA KATEGORYZACJA
}

\begin{abstract}
Ale znowu widzisz - powiada Parmenides - jeżeli ktoś naprawdę, Sokratesie, nie dopuści istnienia postaci rzeczy, spojrzawszy na wszystko co teraz i na rzeczy tym podobne i nie wyróżni żadnej postaci w każdej sprawie szczegółowej, ten ani nie będzie miał dokąd skierować wzroku duszy, nie dopuszczając, żeby istniała idea każdego przedmiotu, zawsze jedna i ta sama, i zabije w sobie całkiem zdolność do mądrej rozmowy.
\end{abstract}

Platon, Parmenides, 135ac

W Ingardenowskiej ontologii można wyróżnić trzy fundamentalne dla sporu o uniwersalia kwestie, które postaram się szczegółowiej omówić:

1. Teoria przedmiotu jest istotna dla sporu o uniwersalia, ponieważ w pojawiających się wokół niego koncepcjach znaczącą rolę odgrywają takie terminy jak „własności”, jak również terminy, które same domagają się szczegółowych dookreśleń, a mianowicie: „wspólne własności”, „przedmiot”, „konkret”.

2. Moment bytowej niesamodzielności i samodzielności - jest to istotna kwestia, ponieważ na gruncie pewnych stanowisk w sporze o powszechniki element abstrakcyjny rozumie się za Arystotelesem jako faktycznie niedającą się oddzielić od konkretu własność (niesamodzielny moment, metafizyczną część); od konkretu - a więc od tego, co egzystencjalnie charakteryzowane jest jako samodzielne.

3. Konkretyzacja - relacja zachodząca między sferą bytów ogólnych (idealnych) a sferą przedmiotów indywidualnych jest niezwykle ważna dla określenia stanowiska realizmu pojęciowego w sporze o powszechniki. Jeśli przyjmiemy przykładowo „zbliżające relacje” - podobieństwa lub jedynie przyporządkowania - jako relacje wiążące obie te sfery, skrajny realizm albo naraża się na zarzut bycia ukrytym nominalizmem, gdyż relacja podobieństwa daje podstawę do traktowania przedmiotu ogólnego jako de facto indywidualnego, choć w swej doskonałej, idealnej wersji (Szymura 2011), albo - jeśli podążymy w odwrotnym kierunku i popadniemy w kolejną skrajność - spotyka się z zarzutem tak dużego oddzielenia sfery idealnej (ogólnej) od indywidualnej, że ta pierwsza staje się niepotrzebnie przyjmowaną nadwyżką onto-

\footnotetext{
${ }_{4}^{4}$ Charakterystykę poszczególnych momentów bytowych wyróżnionych w sposobach istnienia, w tym również momentu bytowej niesamodzielności (jej typów) oraz bytowej samodzielności, można znaleźć w tomie I Sporu o istnienie świata (Ingarden 1987). Szczegółowe analizy momentów bytowych, rezultaty rozwinięcia ontologii egzystencjalnej oraz próby określenia kategorii konkretyzacji przedstawiam w: Barska 2013: 279-290; 2014a: 131-148; 2014b: 271-282.
} 
logiczną5. Jako odrębną kwestię należy traktować pytanie, czy tego typu wykładnia realizmu transcendentnego, traktująca idee jako identyczne pierwowzory (paradeigmata) rzeczy (z tą tylko różnicą, że idealne), jest w jakikolwiek sposób zasadna i przystająca do tego, co głoszą skrajni realiści z Platonem na czele. Można natomiast odnieść wrażenie, że jest to uderzająco niesprawiedliwe uproszczenie teorii idei, i to nie tylko w wersji Ingardenowskiej, ale i Platońskiej6.

Warto w tym miejscu zaznaczyć, że owszem, relacja podobieństwa zachodzi, ale między sferą bytów czysto intencjonalnych a sferą bytów realnych. Świat fikcji, w jednym ze swoich sensów, nie jest niczym innym jak pewnego rodzaju naśladownictwem świata realnego. Dlatego redukcja świata idealnego (czystych jakości idealnych czy idei) do świata intencjonalnego pociąga za sobą relację podobieństwa. Relacja podobieństwa sama w sobie nie przyczynia się bynajmniej do zbliżenia tych światów do siebie. Próba ratowania ontologii Ingardena przed nominalizmem przez przyjęcie intencjonalnego sposobu istnienia idei czy jakości idealnych (intencjonalnego, lecz z fundamentum in re) jest pozorna i niedopuszczalna z kilku powodów, a mianowicie:

a) Zredukowanie idei do bytów intencjonalnych nie zmniejsza, a tym bardziej nie likwiduje transcendencji tych dwóch dziedzin bytowych. Żaden przedmiot czysto intencjonalny nie jest i nie może być składnikiem przedmiotu samoistnego, nie znajduje się w obrębie jego zasięgu bytowego. Przedmioty czysto intencjonalne są samodzielne bytowo. Wykluczone zostają intencjonalne stany rzeczy, gdyż koniecznym egzystencjalnym statusem stanu rzeczy jest niesamodzielność. Nie ma więc intencjonalnych stanów rzeczy z fundamentum in re.

b) Przyjęcie bytów intencjonalnych z fundamentum in re jest jednoznaczne z uznaniem nowego momentu bytowego, gdyż taki byt nie jest ani samo-

\footnotetext{
${ }^{5} \mathrm{Nie}$ jest to cięcie rozwiązujące węzeł gordyjski, jako że koncepcja nominalistyczna natrafia na ten sam problem związany z relacją podobieństwa, a mianowicie regressus ad infinitum (por. Johansson 2009: 21).

${ }^{6}$ Platon miał pełną świadomość pojawiających się wraz z relacją podobieństwa aporii. „W takim razie niepodobna, żeby cokolwiek było podobne do jakiejś postaci albo jakaś postać do czegokolwiek innego. Bo jeżeli tak, to oprócz tej postaci zaraz się pokaże postać inna i jeżeli ta będzie do czegoś podobna, to wystąpi znowu inna i nigdy nie przestanie występować wciąż nowa postać, jeżeli postać ma być podobna do tego, co w niej uczestniczy” (Platon, Parmenides, 132e-133a). Na problem ten zwraca uwagę także Piwowarczyk: „Istnieje pogląd, w myśl którego platonizm jest w rzeczywistości rodzajem nominalizmu (Szymura 2011: 162-163). Tak byłoby oczywiście, gdyby relacja między indywiduum a powszechnikiem zasadzała się na podobieństwie, a sam powszechnik był jakimś indywidualnym prototypem innych indywiduów. Pomysł taki odrzucił już Platon w Parmenidesie” (2014: 112).
} 
istny, ani niesamoistny. Jeżeli coś jest niesamoistne, to nie może być niesamoistne w jakimś stopniu, jest po prostu i całkowicie niesamoistne7. Modyfikując sławną zasadę Davida Armstronga (1978: 115) o „zwycięstwie partykularności”, zgodnie z którą połączenie jednostkowości i ogólności daje zawsze w efekcie jednostkowość, wolno powiedzieć, że połączenie heteronomii z autonomią (o ile byłoby w ogóle możliwe) kończy się zawsze zwycięstwem heteronomii. Poza tym przedmioty odznaczające się bytową heteronomią, a więc przedmioty czysto intencjonalne, są wytworem podmiotu, jego aktów świadomości, i nie mogą mieć swojego fundamentu w rzeczy; sugerowałoby to posiadanie jakiejś pochodnej od rzeczy immanencji jakościowej, a ta jest tożsama z bytową samoistnością. Wynikiem wnikliwej ontologicznej analizy stanów rzeczy jest zresztą teza, która głosi, że negatywne stany rzeczy nie mogą być bytowo niesamoistne (por. Barska 2014a). To, co niesamoistne bytowo, nie może być bytowo niesamodzielne. Stąd w pełni uzasadnione i zrozumiałe wydają się obawy Ingardena związane z tym, że gdyby idee były przedmiotami intencjonalnymi, to przedmioty realne byłyby pewną odmianą przedmiotów intencjonalnych (idealizm metafizyczny), a w rezultacie twierdzenie, że przedmioty realne są samoistne, nie dałoby się utrzymać ${ }^{8}$.

Tylko w przypadku przedmiotów realnych mamy do czynienia z siecią niesamodzielności samoistnych momentów jakościowych. Taka sytuacja nie jest możliwa $\mathrm{w}$ przypadku przedmiotów czysto intencjonalnych, ponieważ same w sobie nie są określone. Takie podejście do momentów bytowych nie jest powszechne, a sugeruje, jeśli wolno tak powiedzieć, że niesamodzielność jest egzystencjalnie silniejsza niż samodzielność, co może być postrzegane jako pewna kontestacja naiwnego poglądu na istnienie. Myśl tę wyraził zresztą Jerzy Gałecki (1964: 49-70), który uznał, że naiwny pogląd na temat istnienia opiera się na założeniu, że najsilniejsze $\mathrm{w}$ istnieniu są byty samodzielne substancje.

c) Uznanie czystych jakości idealnych lub idei za przedmioty intencjonalne spycha koncepcję Ingardena w otchłań nominalizmu, a nie ratuje przed nim.

\footnotetext{
7 Por. Simons 1995: 65: „W swych uwagach na spotkaniu w Krakowie Andrzej Półtawski wskazał na to, że pojęcie przedmiotu częściowo autonomicznego, a częściowo heteronomicznego w sposób oczywisty nie mogłoby wystąpić w myśli Ingardena. (Moglibyśmy powiedzieć, że heteronomia dominuje nad autonomią: cokolwiek jest odrobinę heteronomiczne, jest heteronomiczne tout court)".

${ }^{8}$ Por. Ingarden 1987: 63: „Gdyby myśl ta była słuszna, a idee były zarazem istotnie tylko przedmiotami intencjonalnymi, to czy i przedmioty realne nie musiałyby być także tylko pewną odmianą przedmiotów intencjonalnych? W takim razie myśl, która nam się już w I tomie tych rozważań nasuwała, iż przedmioty realne są samoistne, nie dałaby się utrzymać”.
} 


\section{DLACZEGO REALIZM TRANSCENDENTNY (SKRAJNY)?}

[...] posiadający wiedzę zawsze utrafiać będzie $\mathrm{w}$ to, co jest właściwe, mający zaś słuszne mniemanie, raz trafi w to, drugi raz nie.

Platon, Menon, 97c

Aby wznieść się ponad gąszcz terminologicznych zawirowań oraz merytorycznych trudności i mieć spojrzenie na całość sytuacji, trzeba obrać pewien - chociażby hipotetyczny - punkt widzenia. W związku z tym zakładam, że najbliższa ontologii Ingardena opcja w sporze o uniwersalia to skrajny realizm pojęciowy, rozumiany jako stanowisko głoszące istnienie bytów ogólnych, transcendentnych, niezależnych od podmiotu (istniejących obiektywnie), idealnych, niezależnych od indywidualnych bytów realnych (czasoprzestrzennych). Przyjmuję odpowiednio, że stanowisko nominalistyczne wyklucza istnienie bytów ogólnych - w tym sensie, że albo uznaje je za nieistniejące, albo przez zaakceptowanie pluralizmu egzystencjalnego dopuszcza ich istnienie intencjonalne. Są one wówczas skutkiem czy wytworem aktów świadomości podmiotu. Innymi słowy, nominalista odrzuca „realność” (rzeczywistość) uniwersaliów (bytów ogólnych)9 i przyjmuje jedynie istnienie bytów jednostkowych. Jeżeli przyjmuje „istnienie” bytów ogólnych, to jedynie „w” umyśle (byt intencjonalny).

Można ustawić problematykę sporu o uniwersalia w taki sposób, w jaki proponuje to zrobić Rojek (2019: 164), a mianowicie przyjąć założenie, że realistą jest ten, kto uznaje istnienie nie tyle bytów idealnych/ogólnych, ile bytów wspólnych. Jak należy jednak rozumieć owo „bycie wspólnym”, wzmacniane określeniami: „rzeczywiście”, „prawdziwie”, „faktycznie”? Sam termin „byt wspólny” wzbudza kontrowersje. Dlatego wydaje się, że to właśnie w tym miejscu rozstrzygają się sprawy najistotniejsze dla całej problematyki i jej podziałów.

\footnotetext{
${ }^{9}$ Nie chodzi tu oczywiście o „realne” istnienie w rozumieniu Ingardena, tj. istnienie w czasie i przestrzeni. W takim przypadku tylko naturalista mógłby być realistą. Pomijam również Peirce'owską krytykę platonizmu, rozróżnienia: nominalizm zwykły (w wersji rozszerzonej), nominalizm w szerokim sensie i nominalizm w wąskim sensie. Zresztą zarzut nominalizmu w szerokim sensie, który Peirce wysuwa wobec Platona, zdaje się dotykać - nomen omen - wąskiego rozumienia idei (idea = statyczny wzór). Rzecz komplikuje dodatkowo niejednoznaczna interpretacja owej bezwładności platońskiej idei. Można owo ustatycznienie idei odczytywać jako powtarzalność, regularność, prawo, a więc to, co czyni rzeczy poznawalnymi. Ponadto, jeśli utrzymamy w mocy ograniczenia przyjęte przez Rojka dla bycia prawdziwym realistą - a więc: a) akceptujemy, że jedynym właściwym rozumieniem uniwersale jest byt faktycznie wspólny, b) przyjmujemy, że takie byty istnieją i są nimi np. jakości - to w oczach Peirce’a wciąż będziemy zwykłymi nominalistami (por. Nowak 2013).
} 
Czy realista transcendentny przyjmujący tezę o istnieniu świata idealnego odrzuca tym samym coś „prawdziwie” wspólnego wielu rzeczom? Czy jedyną ścieżką do realizmu, dla realisty transcendentnego, jest swoiście rozumiana partycypacja? Czy w opinii skrajnego realisty każdy byt idealny jest powszechnikiem? Na wszystkie te pytania trzeba odpowiedzieć negatywnie przy odpowiedniej interpretacji tego, co „naprawdę” wspólne. Postaram się więc uwydatnić te aspekty realizmu transcendentnego, które często w atakach na to stanowisko bywają opuszczane, a które są z wielu względów ważne.

Dlaczego w ogóle realizm? Pewnym jest, że Ingarden zawsze daje pierwszeństwo porządkowi rzeczy przed porządkiem słów. Gdyby ująć uniwersale jedynie w jego funkcjonalnym aspekcie, a więc jako coś, co nadaje jedność wielości, to z pewnością - zgodnie z myślą Ingardena - jedność jest niezależna od podmiotu poznającego; w związku z tym uniwersale istnieje w inny niż intencjonalny sposób ${ }^{10}$.

${ }^{10}$ Odwołanie do obiektywności podkreśla ten aspekt platonizmu, który świetnie wyłożył Roger Penrose (2007: 12): „Ale czy świat form matematycznych Platona istnieje w jakimkolwiek rozumnym sensie? Wielu ludzi, włącznie z filozofami, będzie skłonnych uważać ten »Świat « za kompletną fikcję - wytwór wyobraźni niepoddanej żadnym rygorom. A jednak punkt widzenia Platona ma naprawdę głęboki sens [...]. Oczywiście, można przyjąć przeciwny punkt widzenia: można uważać, że sam model istnieje tylko w naszym umyśle, a nie wkładać go do jakiegoś urojonego świata platońskich idei. Jest jednak coś bardzo ważnego, co można zyskać, jeśli się przyjmie, że struktury matematyczne istnieją niezależnie od nas. Tak się bowiem składa, że nasze własne umysły notorycznie wykazują brak precyzji w rozumowaniu, nie można na nich polegać i często wikłają się w sprzecznościach. Dokładność, niezawodność i spójność, jakich wymagają teorie naukowe, potrzebują czegoś więcej niż nasze indywidualne i zawodne umysły. Otóż właśnie te cechy znajdujemy w matematyce. Czy to nie wskazuje nam na jakąś rzeczywistość, która istnieje poza nami? [...] Powiedzieć, że jakieś matematyczne stwierdzenie jest bytem w sensie Platona, oznacza tyle samo co powiedzieć, że jest obiektywnie prawdziwe”. W takiej perspektywie interesujące może być pytanie o warunki możliwości stworzenia czegoś (np. przedmiotu intencjonalnego), czego się nie rozumie. W perspektywie ontologicznej może to być różnica między pojęciem a ideą. Pojęcia nie muszą być „trafnymi znakami rzeczy”, a ich klasa jest szersza niż klasa uniwersaliów (por. Kaczmarek 2006). Można również przytoczyć kolejny ważny argument na rzecz bogatej ontologii (powszechników i ich wewnętrznej różnorodności), na co zwrócił uwagę anonimowy recenzent artykułu — argument z prawdziwości zdań/sądów typu „odwaga jest cnotą”. Oczywiście zagadnienie uniwersaliów ma również długą i bogatą historię w swojej epistemologicznej (logiczno-semantycznej) odsłonie, budowaną zgodnie z pierwotną intuicją, że ogląd świata jest zdeterminowany przez język. Tu analizy prowadzone są w duchu ontologicznym, punkt wyjścia stanowią więc kategorie ontologiczne, będące niejako „przed” kategoriami semantycznymi. Ponadto rekonstrukcja sporu o uniwersalia w analitycznej wersji ma tak obszerną literaturę (również na gruncie polskim - Szkoła LwowskoWarszawska), że pozostaje poprzestać na odniesieniach do pewnych określonych rudymentarnych kwestii (por. Judycki 2020, Grygianiec 2000, 2001). 
Czym jest uniwersale? Gdy odpowiedź brzmi: uniwersalia to przedmioty ogólne, to natychmiast nasuwa się pytanie o rozumienie ogólności. Ogólność charakteryzuje się jako „posiadanie egzemplifikacji”, a więc bycie egzemplifikowalnym, czy też powielalnośćc ${ }^{11}$ (wielość) albo „nieokreśloność” (w sensie posiadania zmiennych). Byty ogólne bywają interpretowane jako „byty wspólne” - w kategoriach „faktycznego”, „prawdziwego”, ,autentycznego” (Rojek 2019, Chrudzimski 2011) bycia „w”, „znajdowania się” jedności „w” wielości ${ }^{12}$. Wydaje się, że w Ingardenowskiej ontologii, gdy określimy uniwersale jako jedność w wielości, to poprawniej byłoby odnieść ów termin do czystych jakości idealnych niż idei ${ }^{13}$. Taką też wersję platonizmu przyjmuje Piwowarczyk ${ }^{14}$.

Dla obu wskazanych przypadków ważna jest interpretacja konkretyzacji, jako że na gruncie tej ontologii zarówno czyste jakości idealne ${ }^{15}$, jak i idee są, $\mathrm{w}$ różnym zresztą znaczeniu, transcendentne wobec przedmiotów indywidualnych. Nadto istnieją w odmienny od nich - a mianowicie idealny — sposób.

Tendencja redukcjonistyczna, która stawia znak równości między ideami, własnościami i uniwersaliami, rodzi wiele trudności. Jeżeli zgodzimy się na

${ }^{11}$ Trzeba dodać, że nie wydaje się słuszne utożsamianie określeń „egzemplifikowalny” i „powielalny” (wyrażającego wielokrotne występowanie). To pierwsze odpowiadałoby bardziej ideom (przedmiotom ogólnym), to drugie - jakościom.

${ }_{12}$ Relacja jedności wobec wielości określana owym „w” nabiera charakteru prawie przestrzennego, fizykalnego. Akcentowanie autentyczności i prawdziwości owego zawierania się jedności w wielości budzi wątpliwości, pojawia się pytanie o rodzaj tej relacji, o jej autentyczny czy też rzeczywisty charakter. Przebijają się tutaj silne tendencje mereologiczne. Jeżeli bycie jedności w całości rozumie się jako relację bycia częścią lub bycia własnością, to w pełni zrozumiałe i jasne stają się obiekcje Ingardena. Nasuwa się pytanie o to, co stoi za postrzeganiem Ingardena jako nieświadomego platońskiego nominalisty. Być może zarzut ten opiera się na nieuświadomionych tendencjach naturalistycznych oraz mniej lub bardziej świadomych tendencjach nominalistycznych, rozumianych w klasycznym znaczeniu?

${ }_{13}$ Paradoksalnie, przy uwzględnieniu wielości znaczeniowej pojęcia „jedność”, kwestia ta nie jest wcale oczywista. Gdy położymy nacisk na „organizujący” i „określający” aspekt jedności, a także weźmiemy pod uwagę znaczenie czystej możliwości w roli określającej to, czym dana rzecz jest i jaka jest, idee wysuwają się na plan pierwszy.

${ }_{14}$ Por. Piwowarczyk 2020: 114: „za właściwą formę platonizmu uważam tę, w której uniwersaliami są tzw. jakości idealne”. Andrzej Nowak (2013: 270) sugeruje również, że tego typu wykładnia platonizmu jest bliska Ingardenowi, a pod pewnymi warunkami akceptowalna przez C. S. Peirce'a: „Gdyby Peirce znał opinię Ingardena, że idee u Platona są po prostu czystymi jakościami idealnymi, zapewne w chwili wolnej od zacietrzewienia podpisałby się pod nią".

${ }^{15}$ W Ingardenowskich kategoriach ontologicznych czyste jakości idealne są „przedmiotami” jedynie w rozumieniu przedmiotów jako „czegoś w ogóle”. Natomiast czysta jakość idealna nie jest przedmiotem sensu stricto, a więc nie posiada formy przedmiotowej „podmiot własności - własności”, nie jest także przedmiotem sensu largo, a więc złożeniem formy, materii, sposobu istnienia. 
to, że ogólność jest rozumiana jako możliwość egzemplifikacji, powielanie własności w wielu przedmiotach, to jakim sposobem przykładem ogólnej własności (universale) jest bycie centaurem, bycie jednorożcem czy bycie Katarzyną Barską? W jakim sensie ostatni z wymienionych wariantów może być czymś numerycznie identycznym lub tylko podobnym w wielu różnych indywiduach? $\mathrm{W}$ jakim znaczeniu jest zbieżny z określeniem własności (universale) jako zasady: est unum in multis et de multis? Czy idea (universale) w ten sam sposób odnosi się do realnych (aktualnych, nieaktualnych - przeszłych lub przyszłych) i intencjonalnych przedmiotów? A więc czy „bycie Lepperem” (Chrudzimski 2011) traci swą funkcję „bycia własnością” w roku 2012? Tego rodzaju przykłady prowadzą do kolejnych trudności: otóż określenie „bycie Lepperem” czy „bycie centaurem"16 nie wskazuje na własność przedmiotu (concretum czy individuum), ale na jego „co”, akcentuje podmiotowość - a więc to, co rzecz w sobie uosabia, bądź to, co rzecz konstytuuje jako tę właśnie, a nie inną. Każdy z wymienionych przypadków uwidacznia więc różnie rozłożone akcenty: przykład pierwszy eksponuje momentum individuationis, a w drugim na plan pierwszy wysuwa się istota lub sposób istnienia.

W tej sytuacji pomocne okazuje się nie tylko przywołanie rozróżnienia między universale przypadłościowym a substancjalnym $\mathrm{w}$ porządku horyzontalnym, lecz także wskazanie na pełnienie przez nie radykalnie innej funkcji niż ta, którą pełni własność w przedmiocie ${ }^{17}$.

Platonikom zarzuca się, że uznają istnienie własności, które nie mają swoich egzemplifikacji w świecie realnym. Założenie to staje się niedorzeczne $\mathrm{w}$ ujęciu redukcjonistycznej konwencji głoszącej, że istnieć znaczy tyle, co być w czasoprzestrzeni, a co więcej utrzymywanie tej konwencji sprawia, że platonicy muszą jawić się jako nominaliści. Z tej perspektywy realiści umiarkowani (immanentni) wypadają znacznie lepiej, ponieważ odrzucają istnienie tychże własności, a także mogą zaakceptować realność praw ${ }^{18}$. Ale czy jest to równoznaczne z tym, że platonik miałby uznawać idealny status istnienia własności „bycia centaurem”, która „czeka” w platońskim niebie na możliwość realizacji w świecie realnym, jeśli ten dodatkowo dla platonika jest co naj-

${ }^{16}$ Skądinąd centaury mogłyby być przykładem konkretnych bytów ogólnych, a więc „niedookreślonych” w sensie niedookreśloności przedmiotów intencjonalnych, a być może także powielalnych, ale nie samodzielnie istniejących własności, które są nieegzemplifikowalne. Innymi słowy, sensowne jest mówić o ich samodzielności, gdy uznamy je za przedmioty intencjonalne.

${ }_{17}$ Zagadnienie przyporządkowania funkcji egzemplifikacji (podpadania) i przysługiwania (niesamodzielności) odpowiednim bytom zostało znakomicie zilustrowane i omówione przez Piwowarczyka (2014).

${ }^{18}$ Jak wskazuje Nowak (2013), w opinii Peirce’a Platon o tyle był nominalistą, o ile wykluczał realność praw ogólnych. 
mniej słabszy egzystencjalnie, zwłaszcza w rzeczonym przykładzie, gdy mowa przecież o cieniu cienia? Gdy spojrzymy na tę kwestię z metapoziomu, możemy zapytać: czy faktycznie jest tak, że platonicy grzeszą nadmiarową ontologią? A może bardzo łatwo przychodzi wydać taki sąd z pozycji już określonego stanowiska w kwestii tego, co naprawdę istnieje? Skądinąd warto się zastanowić, czy kiedy odrzucamy bogatą ontologię egzystencjalną (np. Ingardenowską), nie odbieramy sobie tym samym szansy na analizę pewnych niezwykle płodnych filozoficznie zagadnień, takich jak: stosunek idei do przedmiotów realnych i intencjonalnych; ewentualne różnice między bytami realnymi, możliwymi, intencjonalnymi i idealnymi, a więc określenie różnicy pomiędzy ideą centaura, kwadratowego koła, Andrzeja Leppera i Katarzyny Barskiej aktualnie piszącej te słowa; zagadnienie różnych wariantów intencjonalnej egzemplifikacji wraz z jej specyfiką związaną z całym bogactwem teorii przedmiotu intencjonalnego ${ }^{19}$. Czy można $\mathrm{w}$ związku $\mathrm{z}$ tym mówić o dwóch rodzajach uniwersale (fikcyjnym i niefikcyjnym)? Jaka byłaby różnica między fikcyjnym uniwersale a jego egzemplifikacją?

Podobnie, czy platonik naprawdę przyjmuje samodzielność tego, co rozumiemy jako własność przysługującą przedmiotowi ${ }^{20}$ ? Gdy traktujemy realistę jak kogoś, kto uważa, że własności są bytami ogólnymi, a więc: a) albo $\mathrm{w}$ wersji umiarkowanej - istnieją w konkretach jako numerycznie identyczne (przy dosłownym rozumieniu jedności $\mathrm{w}$ wielości), b) albo - w wersji skrajnego realizmu - istnieją samodzielnie jako własności w „wyobrażanym” platońskim niebie, a oprócz tego jeszcze b') stanowią idealną (doskonałą), choć indywidualną wersję (prototyp) indywidualnych przedmiotów, które pod nie podpadają, to trzeba uznać, że reprezentuje on stanowisko bardzo trudne do obrony. Czy są to jednak sprawiedliwe, rzeczowe, trafne i pełne reinterpretacje

19 Problematyka przedmiotu intencjonalnego jest niezwykle złożona. Często gdy posługujemy się terminem „przedmiot intencjonalny”, ulegamy pokusie pominięcia bogatego kontekstu, w który jest on uwikłany, i traktujemy ów przedmiot intencjonalny jak przedmiot realny, ale istniejący w odmienny - intencjonalny - sposób. Ingarden nie tylko rozróżnia wiele typów przedmiotów intencjonalnych, lecz także zwraca uwagę na: a) szczególną ich budowę (zawartość - struktura), b) podwójne upodmiotowienie, które zmienia np. charakter własności „bycia centaurem”, c) proces zwijania i rozwijania przedmiotów intencjonalnych przez akty świadomości, który może wpływać na rozumienie egzemplifikacji, d) istnienie miejsc niedookreślenia, a więc specyficzne konstytuowanie się tożsamości przedmiotów intencjonalnych.

${ }^{20}$ Idee (byty inteligibilne) są oczywiście samodzielne w Ingardenowskim rozumieniu, ale z tego samego powodu nie są własnościami, albowiem te zawsze są niesamodzielne względem przedmiotu jednostkowego. Dla Platona przedmioty jednostkowe (empiryczne) zdają się - w sensie Ingardena - samodzielne i zależne od idei: nie mogą istnieć bez wzorca. 
platonizmu ${ }^{21}$ ? Niewykluczone, że natrafiamy tutaj na paralogizm polegający na przyjęciu uproszczonej lub zniekształconej wersji stanowiska realizmu i wyciąganiu na tej podstawie wniosków.

Trzeba by osobno rozważyć, czy nie mamy do czynienia z nadużyciem polegającym na przyjęciu tezy, zgodnie z którą realistą w kwestii powszechników może być tylko ten, kto uznaje „faktyczną”, „rzeczywistą”, ,autentyczną” jedność w wielości (por. Rojek 2019: 49). Każdy, kto tego nie uczyni, jest jawnym bądź ukrytym nominalistą, schowanym za fasadą bytu wyobrażonego, który śmie błędnie nazywać idealnym. Przy rozumieniu relacji między powszechnikami a indywiduami jako rzeczywistej jedności w wielości (intencjonalny powszechnik z fundamentum in re) można podać wiele argumentów za tym, że nie jest wcale oczywiste, jakoby stanowiska, które uważa się za spełniające to wymaganie, naprawdę je spełniały. Wolno oczywiście interpretować relację między ideą a jej egzemplifikacją w ograniczeniu do relacji naśladownictwa (mimesis), a jednocześnie chcieć przypisać relację uczestnictwa (metheksis) bytom intencjonalnym, zakotwiczonym w bytach realnych. Ale wiele wskazuje na to, że parafrazując słowa Armstronga - ożenek intencjonalności z metheksis jest niemożliwy, ponieważ intencjonalność pozostaje $\mathrm{w}$ bliskim, i zdaje się wyłącznym, związku z mimesis. A taka relacja nie jest żadnym rzeczywistym byciem jedności w wielości, które ma gwarantować realizm ${ }^{22}$. W takim zawęża-

${ }^{21}$ Trudność, o której wspomina Orygenes („Platona nikt nie zna w pełni”), nie powinna być wpisywana w strategię argumentacji na rzecz proponowanych odczytań myśli Platona. Taki wybieg wydaje się niczym nieuzasadniony. Zgadzam się z Nowakiem (2013), że pod taką wykładnią platonizmu nie podpisałby się żaden platonik. Największą przeszkodą w rozumieniu Platona - jak pisze Bogdan Dębiński (1997: 191) - jest nasza własna skłonność do myślenia konkretnego o rzeczach abstrakcyjnych, podczas gdy Platon posiadał umiejętność do myślenia abstrakcyjnego o rzeczach bardzo konkretnych.

${ }^{22}$ Można jeszcze inaczej, i zdaje się w pełni zasadnie, interpretować platońskie relacje mimesis i metheksis: nie jako dwie relacje alternatywne, ale jako dwa kierunki tej samej relacji partycypacji (idea - rzecz), pamiętając przy tym o odmiennych ontycznych statusach jej elementów. Kierunek „od idei do rzeczy” byłby uczestnictwem (obecnością), natomiast odniesienie „od rzeczy do idei” byłoby naśladownictwem (imitacją). Utożsamienie idei z przedmiotem intencjonalnym zaburza tak ustalony kierunek, albowiem to przedmiot intencjonalny imituje rzecz, a nie odwrotnie (por. Ross 1951, Dębiński 1997). Jak pisze Dębiński (1997: 97): „Uznać trzeba przede wszystkim, że uczestnictwo stanowi określony rodzaj relacji między tym, co uczestniczy, i tym, w czym uczestniczy to, co uczestniczy. Relacja wyraża określoną postać związku, w jakim pozostają człony relacji. Związek ten pojmuje Platon na dwa sposoby, wyróżniając dwie jego postacie; są nimi obecność ( $\pi \alpha \rho \circ \sigma^{\prime} \alpha$ ) i naśladownictwo. Zależnie od kierunku, w jakim przebiegać będzie analiza relacji (czy od tego, co uczestniczy, w kierunku tego, w czym uczestniczy, czy też odwrotnie), będziemy mieli do czynienia z obecnością bądź naśladownictwem. Jeżeli rozważana będzie taka relacja idei do zjawiska, której punktem wyjścia uczynimy ideę, punktem dojścia zaś zjawisko, to powiemy o uczestnictwie przejawiającym się pod postacią obecności idei w zjawisku. Jeżeli natomiast analizie 
jącym oświetleniu, opierającym realizm na relacji „faktycznego” bycia jedności w wielości, realizm immanentny jest równie wątpliwym realizmem jak realizm transcendentny, a stanowiska spełniające ten warunek (Armstrong) niosą ze sobą ogrom paradoksów (problem teorii przedmiotu, wielokrotna lokalizacja, identyczności egzemplifikacji, a nadto wszystkie trudności aposterioryzmu). W związku z tym wydaje się, że mamy do czynienia z fałszywym dylematem: albo przyjmuje się „prawdziwą” jedność w wielości i zostaje się „prawdziwym” realistą, albo trzeba zostać nominalistą jakiegoś typu.

Realizm immanentny nie unika kłopotów realizmu skrajnego, a może nawet dzieli z nim dokładnie te same trudności. Przyjmując universale jako „część" particulare, natrafiamy na problem z określeniem charakteru owej relacji. Nie może to być część w sensie przestrzennym, czasowym, funkcjonalnym czy logicznym (por. Johansson 2009). Przyjąwszy zaś wymóg: dla istnienia uniwersale konieczne jest istnienie przynajmniej jednej egzemplifikacji (nawet in spe), odwracamy po prostu kierunek egzystencjalnej zależności universale/particulare ${ }^{23}$.

Zbyt pochopne wydaje się formułowanie wniosku o odrzuceniu przez Ingardena platońskiej metheksis ze względu na trudności, jakie ze sobą niesie (por. Rojek 2019)24. Zdaje się to prowadzić do przekonania, że Ingarden wy-

poddamy relację odniesienia zjawiska do idei i punktem wyjścia uczynimy zjawisko, możemy mówić o uczestnictwie, które przejawia się w postaci naśladownictwa”.

${ }^{23} \mathrm{~W}$ duchu naturalistycznym (Armstrong) uzasadnia się konieczną egzystencjalną zależność uniwersale od swej egzemplifikacji czy też realizacji brakiem pomysłu na to, gdzie miałoby się podziać samo niezrealizowane uniwersale. Istnienie niezrealizowanych uniwersaliów zakłada więc ich transcendencję. Oczywiście cały problem nabiera innych odcieni, gdy postaramy się spojrzeć na platońskie „miejsce nadniebne” „oczyma duszy” i uświadomimy sobie, że Platon ma tu na myśli nie tyle miejsce bytowania idei, ile ich status ontyczny (por. Dębiński 1997: 48).

24 Rojek 2019: 165: „Pojęcie $\mu \varepsilon \varepsilon \varepsilon \varepsilon \xi \iota \varsigma$ faktycznie prowadzi do trudności. Żeby je usunąć, Ingarden odrzucił $\mu \varepsilon \dot{\varepsilon} \theta \varepsilon \xi \varsigma$ i pozostawił dziedzinę transcendentnych idei. Należy jednak, zdaje się, raczej odrzucić dziedzinę transcendentnych idei i przyjąć $\mu \varepsilon \varepsilon \varepsilon \xi \xi \iota$. Tylko w ten sposób można pozostać realistą w kwestii uniwersaliów. Teoria uniwersaliów Ingardena kończy się więc fiaskiem”. Rzecz w tym, że dla Ingardena Arystotelesowska koncepcja

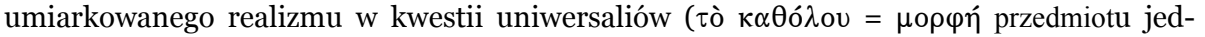
nostkowego) jest tak samo niemożliwa do przyjęcia jak absurdalne i mitologizujące rozumienie $\mu \varepsilon \varepsilon \varepsilon \varepsilon \xi ı \varsigma$ jako stosunku zawierania się idei w bytowym obrębie przedmiotu pod nią podpadającego, a więc rozumienie idei jako składnika bytu jednostkowego, czegoś co jest w stosunku do niego strukturalnie immanentne. Jeżeli cokolwiek Ingarden odrzuca, to właśnie taką interpretację $\mu \varepsilon \varepsilon \theta \varepsilon \xi ı \varsigma$ i dzieje się tak nie tylko ze względu na tzw. „problem z oddzielenia”. Ingarden ma pełną świadomość tego, że takie rozumienie (część-całość) $\mu \varepsilon ́ \theta \varepsilon \xi ı \varsigma$ w żaden sposób nie tłumaczy związku przynależności (szczególnej relacji) między dziedziną idei (czy nawet dziedziną pojęć) a przedmiotami indywidualnymi. Czy Ingardenowska krytyka Platona jest słuszna, to oddzielna kwestia (por. Ingarden 1961, t. II: 64, 104, 472). 
lewa dziecko z kąpielą, tymczasem odrzuca on jedynie interpretację metheksis, która każe traktować ideę jako część przedmiotu pod nią podpadającego25. Idea jako taka, wraz ze swoją formą, materią, sposobem istnienia, w żadnym razie nie stanowi, i stanowić nie może, części przedmiotu jednostkowego. Jedność, odpowiedniość i przyporządkowanie idei i przedmiotu opiera się na jedności jakości, materialnego uposażenia, które dzięki konkretyzacji wchodzi w nową formę i istnieje na swój sposób.

Podobnie już w dialogach Platona doszukać się można koncepcji pryncypiów bytowych Jedna i Nieokreślonej Dyady, na których oparta jest późna (niepisana) nauka Platona. Są więc powody, by sądzić, że związek między Jednością a Wielością (Jedno - Hen i Nieokreślona Dyada) jest „wcześniejszy” od relacji idea-zjawisko, a jednocześnie stanowi warunek konieczny zrozumienia tej relacji (por. Dębiński 1997, Gadamer 1985). Można zaryzykować twierdzenie, że idea bardziej odzwierciedla relację jedność-wielość, która „dzieje się" na metapoziomie, w obszarze przedontologicznym, aniżeli jest tej relacji elementem. Dlatego w myśli platońskiej jedność i wielość oraz analogicznie ruch (zmienność) i bezwład nigdy de facto nie zostały radykalnie oddzielone na poziomie bytu (por. zarzuty Peirce'a). W tej perspektywie także nie ma żadnej przepaści czy oddzielenia między światem idei a światem zjawisk (por. zarzuty Ingardena). Nie są to byty izolowane, dla których trzeba szukać zewnętrznych powiązań, partycypacja nie jest czymś zewnętrznym (por. Rojek 2019: 53). Współmiernie rzecz się ma mutatis mutandis w myśli Ingardena: idea jest zawsze ideą czegoś, choć owo coś nie zawsze jest przedmiotem realnym $^{26}$. W tak zarysowanym paradygmacie niełatwo utrzymać stanowisko głoszące, że przypisywanie uniwersale idealności istnienia jest niczym innym jak spychaniem na margines problematyki jedność-wielość (Rojek 2019: 30).

Jeżeli idealność qua idea jest w ogóle związana z powtarzalnością, powielalnością, bytem wspólnym, to tylko pośrednio, przez sieci związków koniecznych. Natomiast bezpośrednio i ściśle wiąże się ona z tym, co określane bywa mianem „przedmiotu ogólnego”, „niezupełnego” (Meinong), „ponadczasowego” (Whitehead). W Ingardenowskim sensie jest to idea, która posiada także zmienne (czyste możliwości). Tym samym całe bogactwo, które wpisuje się

25 Co ciekawe, przy takiej interpretacji metheksis, jedynym rozsądnym powodem przyjęcia jednocześnie „nadmiarowego” istnienia idei, poza bytem jednostkowym, mogłaby być chęć uniknięcia utożsamienia tego, co egzemplifikowalne, ze swoją własną egzemplifikacją. Tego typu utożsamienie niektórym filozofom nie wydaje się jednak problemem (por. Loux 2006: 19), choć rodzi przecież wiele wątpliwych konsekwencji (np. problem z wyjaśnieniem zachowania ciągłości, przynależności czy tożsamości).

${ }^{26}$ Można by zaryzykować stwierdzenie, że „indywidualność” idei to jedynie refleks indywidualności przedmiotu. 
przecież w myślenie o uniwersale, zostaje unieważnione i potraktowane jak niepotrzebny i wymyślny parawan, stworzony, aby ukryć grzech nominalizmu.

Przypisywanie Ingardenowi ontologicznego oddzielenia jedności od wielości (Rojek 2019: 166) oparte jest na błędnym odczytaniu założeń Ingardena o odpowiedniości własności (materii własnościowych) i jakości, przy czym pomija się niezwykle dla niego ważną i innowacyjną dla koncepcji idei relacyjną czy „relacjonalną” ${ }^{77}$ rolę czystej możliwości ${ }^{28}$. Nie jest prawdą, że na poziomie czystych jakości idealnych czerwień i zieleń się wykluczają. Będzie jeszcze o tym mowa.

W tym miejscu należy podkreślić znaczenie zmiennych $\mathrm{w}$ koncepcji Ingardena. Lekceważenie doniosłej pozycji zmiennych powoduje, że powracamy do bajkowego obrazu idei, w którym idea/wzór staje się zbędną dla zrozumienia rzeczy/zjawisk oraz ich natury ontologiczną nadwyżką. Pewne formalne uwarunkowania, takie jak dwustronność budowy idei, istnienie zmiennych, sieci związków koniecznych, które gwarantują pewną odpowiedniość bytu idealnego i realnego, również wykluczają możliwość tzw. „składania się” bytu realnego z idealnym. Tę możliwość przede wszystkim wyklucza jednak przyjęte przez Ingardena założenie jedności sposobu istnienia, a więc jedna $\mathrm{z}$ wyjściowych tez, mówiąca o tym, że każdy przedmiot i wszystko w jego obrębie istnieje tylko w jeden określony sposób. Dlatego Ingarden nie mógłby się zgodzić z twierdzeniem realizmu immanentnego odnośnie do „złożenia” jednostkowego przedmiotu realnego i ogólnego przedmiotu idealnego, rozumianego jako własność - ze względów nie tylko egzystencjalnych, lecz także formalnych. Choć w jednym punkcie zapewne byłby zgodny z J. P. Morelandem - że egzemplifikacja jest bardzo szczególną relacją i nie da się jej sprowadzić do relacji przestrzennego zawierania się, analogicznie do tego, jak zawiera się piasek w wiaderku (por. Rojek 2019: 56, Moreland 2001).

Nawet jeśli puścimy wodze fantazji i założymy, że na gruncie Ingardenowskiej ontologii połączenie bytu idealnego (ogólnego) z realnym (jednostkowym) jest możliwe, a w rezultacie otrzymuje się całość, tj. byt realny jednostkowy, to wciąż nie będzie jasności co do tego, dlaczego zwycięża byt realny, a nie idealny. Gdybyśmy podążyli dalej tym tropem i podstawili za byt idealny byt intencjonalny, taka wariacja, prowadząca do połączenia bytu realnego z intencjonalnym, skutkowałaby zwycięstwem bytu intencjonalnego.

\footnotetext{
${ }^{27}$ W rozumieniu Ingardena (1961: 106, por. Hartmann 1966).

${ }^{28}$ Wydaje się, że jest to kolejny czynnik przekreślający ewentualność postawienia znaku równości między konkretyzacją a pewną wersją odczytania platońskiej partycypacji - kolejny obok różnicy poziomów rozważań, na którą wskazuje Jacek Widomski (2003), a mianowicie różnicy między poziomem metafizycznym (Platon) a ontologicznym (Ingarden).
} 


\title{
3. DLACZEGO NIE REALIZM IMMANENTNY (UMIARKOWANY)?
}

\author{
Wychodzenie pod górę i oglądanie tego, co jest tam wyżej, jeśli \\ weźmiesz za wznoszenie się duszy do świata myśli, to nie \\ zbłądzisz i trafisz w moją nadzieję, skoro pragniesz ją usłyszeć.
}

Platon, Państwo, 517b

Zacznę od naświetlenia pewnych trudności natury terminologicznej, które pojawiają się przy zestawieniu Ingardenowskiej ontologii z problematyką uniwersaliów:

a) Nieporozumień może przysporzyć interpretacja inherencji. Inherencja może być rozumiana jako odpowiednik momentu bytowej niesamodzielności. Inherencja jest relacją istotną dla pewnych stanowisk w sporze o uniwersalia. Bywa ona charakteryzowana jako niesamodzielny moment, wyabstrahowany z całości (konkretu), który nazywany jest abstraktem. W Ingardenowskiej ontologii niesamodzielność jest relacją między niesamodzielnymi momentami w całości, całość ta - konkret - może być już samodzielna.

b) Kolejny problem, na który można natrafić, zestawiając ontologię Ingardena $\mathrm{z}$ pewną grupą stanowisk w sporze o powszechniki, to rozumienie przedmiotu i własności. Niejednokrotnie określa się własność np. jako czerwoność danej róży. Trzeba mieć świadomość, że ontologia Ingardena rozpada się na trzy ważne części: egzystencjalną, formalną i materialną. Zgodnie z tym przedmiot sensu stricto ma formalną strukturę: „podmiot własności - własności”. Własność więc może być rozumiana wąsko, a więc czysto formalnie jako niesamodzielna wobec podmiotu, oraz szeroko, czyli jako forma własności przedmiotu wraz z jej uposażeniem - „barwą czerwoną”, a więc materią skonkretyzowaną w formie własności przedmiotu. Przedmiot w tej koncepcji nie jest jedynie zlepkiem uposażonych własności, posiada bowiem podmiot, który także nie jest tylko czystą formą, substratem, ale konkretyzują się w nim materie, czyli natura konstytutywna. Posługuję się przy tym uproszczeniami, by jedynie zwrócić uwagę na kwestie, które mogą stanowić przyczynę nieporozumień.

c) Konkretność czy też indywidualność na równi wiąże się z formą „podmiot własności - własności”, jak i ze złożonością, rozumianą jako zrośnięcie, na co wskazuje etymologia (concrescere - razem rosnąć, zrastać się). Stąd Ingarden mówi o przedmiocie pierwotnie indywidualnym, prostym w takim sensie, że nie jest on sumą części, a czymś na podobieństwo monady. Swoją samoistność i samodzielność zawdzięcza jakościowym splotom, których efektem jest „forma I”, i wraz z nią dopiero tworzy konkret. Jednostkowość również bywa wiązana $\mathrm{z}$ istnieniem. 
Jak już wspomniałam, zestawiając ontologię Ingardena z pewnymi stanowiskami w sporze o uniwersalia, będę odwoływać się do artykułu Pawła Rojka (2008: 45-61), w którym autor rekonstruuje trzy, jego zdaniem, zasadnicze pojęcia uniwersaliów.

$$
\begin{aligned}
& \text { 3.1. UNIWERSALIA ROZUMIANE JAKO WSPÓLNE WŁASNOŚCI (ABSTRAKCYJNE } \\
& \text { UNIWERSALIA) - STANOWISKO OKREŚLANE JAKO ABSTRAKCYJNY REALIZM }
\end{aligned}
$$

- Arystotelesowska relacja inherencji zachodząca między tym, co abstrakcyjne, a tym, co konkretne, w pewnym sensie odpowiada Ingardenowskiemu momentowi bytowej niesamodzielności. Abstrakty nie mogą jednak istnieć, nie będąc w konkretach ${ }^{29}$. Przykładem tej relacji jest stosunek przedmiotu i własności czy też podmiotu i własności, by posłużyć się Ingardenowskimi kategoriami. Pojawia się tutaj pewne rozróżnienie, mianowicie ową inherencję, „zależność bytową”, „tkwienie w”, „przysługiwanie” rozumie się dwojako: a) gatunkowo (przechodnie tropy i realizm abstrakcyjny): aby dana własność istniała, musi istnieć jakiś przedmiot, który ją posiada, a nie dokładnie ten, do którego należy; b) w teorii nieprzechodnich tropów mówi się o „indywidualnej” zależności jednostkowej własności od przedmiotu, w którym ona faktycznie inheruje. Abstrakcyjność i konkretność definiuje się w odniesieniu do pierwotnej relacji inherencji - jest ona zwrotna, przechodnia i antysymetryczna. Tak więc to, co abstrakcyjne, jest tym, co inheruje w czymś różnym od siebie. Absolutnie abstrakcyjne jest więc ostatecznie to, co zawiera się w czymś różnym od siebie, ale w nim nie zawiera się nic różnego od niego. I odpowiednio, absolutny konkret to to, w czym inherują różne składniki, natomiast on sam w niczym nie inheruje (substancje pierwsze Arystotelesa).

- Coś jest więc abstrakcyjnym uniwersale (AU), jeśli inheruje w co najmniej dwóch różnych przedmiotach (rzeczach jednostkowych - konkretnych particulare, CP), np. ogólna biel. Abstrakcyjne particulare (AP) inheruje w jednej rzeczy, np. jednostkowa biel. Arystotelesowska substancja druga konkretne uniwersale (CU) - jest orzekana o substancji pierwszej, nie jest jednak pewne, czy w niej inheruje. Przyjmuje się, że tak - na zasadzie: „Człowiek znajduje się we wszystkich poszczególnych ludziach”. Splotem jest więc tutaj relacja inherencji, określana przez niektórych jako „nierelacyjny węzeł” (por. Bergmann 1964, Armstrong 1989), odnosząca do konkretu (CP)

${ }^{29}$ Donald C. Williams (1997: 121) zrywa z rozumieniem abstrakcyjności jako tego, „co zawiłe, eteryczne, umysłowe, racjonalne, bezcielesne, idealnie doskonałe, pozaczasowe, pierwotne lub ostateczne, czysto teoretyczne, niebezpiecznie spekulatywne i wizyjne [...], co puste, niewystarczające, nierzeczywiste, tylko potencjalne, po prostu wyobrażone i nierealne". 
konkretne uniwersale, odpowiadające kategorii substancji, i (AU) abstrakcyjne uniwersale, odpowiadające akcydensom.

- Tym, co jest jedynym w wielości, jest wspólna, numerycznie identyczna $\mathrm{w}$ wielu rzeczach własność (realizm umiarkowany).

Ingardenowska ontologia wyklucza stanowisko realizmu abstrakcyjnego, przede wszystkim ze względu na odmienne podejście do własności. $\mathrm{W}$ tym miejscu krótko zrekonstruuję Ingardenowską teorię przedmiotu. Własności $\mathrm{w}$ ontologii Ingardena zawsze są własnościami konkretnego indywidualnego przedmiotu, dlatego same są równie indywidualne. Przedmiot indywidualny posiada formalną strukturę: „podmiot własności i własności”. Jest to najwęższe rozumienie przedmiotu w tej ontologii, obok przedmiotu sensu largo jako złożenia materii, formy i sposobu istnienia lub przedmiotu jako „czegoś w ogóle”.

Interesujące jest to, że własności są indywidualne dzięki „relacji inherencji”, która u Ingardena ma swój odpowiednik w postaci momentu bytowej niesamodzielności. Podstawowa struktura przedmiotowa: „podmiot własności i własności” jest pewną formalną jednością, ponieważ mamy tu do czynienia $\mathrm{z}$ niesamodzielnością bytową o charakterze formalnym między podmiotem a własnościami. W związku z tym, jeżeli mówimy o własnościach, to zawsze będą to indywidualne własności, należące do indywidualnego przedmiotu. Własności, które przynależą do tego przedmiotu, są jego własnościami. Ponadto, pewne twierdzenia ontologii egzystencjalnej wykluczają możliwość przyjęcia wspólnych własności inherujących w przedmiotach indywidualnych. Jak już podkreślałam wcześniej, inherencja jest odpowiednikiem bytowej niesamodzielności, a ta $\mathrm{w}$ ontologii Ingardena definiowana jest następująco: $M$ jest niesamodzielne względem $M 1$, jeżeli istnienie $M$ jest uwarunkowane koniecznym wspólistnieniem z M1 w całości C; nie bez znaczenia jest dopowiedzenie „w całości C”, stąd przedmioty, w których inherują wspólne własności, musiałyby tworzyć wspólną całość $\mathrm{C}$, a więc w ujęciu Ingardena być jednym przedmiotem indywidualnym.

Podsumowując, pewne twierdzenia ontologii formalnej i egzystencjalnej wykluczają możliwość przyjęcia stanowiska realizmu abstrakcyjnego.

Gdyby chcieć jednak przeinterpretować pewne tezy realizmu abstrakcyjnego i przyjąć uniwersale-jakość, a nie uniwersale-własności, to odpowiednikiem abstrakcyjnego uniwersale mogłaby być czysta jakość idealna (ogólna biel) lub jej ogólna konkretyzacja w zawartości idei, natomiast abstrakcyjnym particulare byłaby wówczas materia własności pewnego indywiduum. Jednakże w pierwszym wariancie relacja inherencji, rozumiana jako niesamodzielność bytowa, byłaby niemożliwa. I to nie tylko w dwóch różnych przedmiotach, ale nawet w jednym, gdyż zarówno czyste jakości idealne, jak 
i składniki zawartości idei nie są (i być nie mogą) niesamodzielne względem przedmiotu indywidualnego. Natomiast w przypadku abstrakcyjnego particulare (np. jednostkowej czerwieni) sprawa wydaje się niejasna, ponieważ albo mamy do czynienia $\mathrm{z}$ niesamodzielnością bytową o charakterze formalnym, albo jedynie $\mathrm{z}$ faktycznym wspólistnieniem $\mathrm{w}$ obrębie jakieś całości (przedmiotu). Jakość czerwieni, skonkretyzowana w formie własności jakiejś róży, na poziomie przedmiotowym wcale nie jest niesamodzielna (materialnie) względem róży (jej podmiotu). Może być niesamodzielna jedynie formalnie, a więc ze względu na formę bycia własnością. I odwrotnie, róża jako taka nie jest niesamodzielna względem czerwieni, może być przecież żółta, biała itp.

Konkretne uniwersale z kolei może skonkretyzować się jako materialny moment natury konstytutywnej przedmiotu, natomiast sama ta natura może być materialnie samodzielna i nie wchodzić w związki o charakterze egzystencjalnej niesamodzielności z materialnymi momentami własności.

Spróbuję od innej jeszcze strony pogodzić stanowisko realizmu abstrakcyjnego z Ingardenowską ontologią, wprowadzając kolejną modyfikację, która polega na zamianie relacji inherencji na konkretyzację. Uznam więc, że abstrakcyjne uniwersale i konkretne uniwersale konkretyzuje się $\mathrm{w}$ wielu przedmiotach. Pierwsze - przynajmniej w dwóch, zwykle jako materia własności; drugie - w wielości podpadającej pod najwyższy gatunek, zwykle jako materia podmiotu. A abstrakcyjne particulare - moment jakościowy, który może konkretyzować się jedynie w jednym jedynym przedmiocie - musi być wówczas potraktowane jako swoisty, indywidualizujący moment materialny, stanowiący naturę konstytutywną przedmiotu. Trudno jednak się zgodzić, że mogłaby to być jednostkowa biel. Rzecz jasna, tego rodzaju modyfikacja wydaje się zbyt silna. Zaburza podstawową strukturę stanowiska realizmu abstrakcyjnego, jako że relacja inherencji jest zasadnicza dla odróżnienia tego, co abstrakcyjne, i tego, co konkretne. Problematyczne jest zastępowanie inherencji konkretyzacją, gdyż nie wyklucza ona istnienia tego, co się konkretyzuje, jako nieskonkretyzowanego.

Podsumowując, dotychczasowe analizy pokazują, że nawet po wprowadzeniu znaczących zmian stanowisko realizmu abstrakcyjnego w żaden sposób nie jest zbieżne z Ingardenowską ontologią. Główną przeszkodę stanowi to, że realizm ten przyjmuje, iż to, co ogólne, jest niesamodzielną własnością. Co ciekawe, Rojek sam wskazuje na tego typu trudności, a cytując Bocheńskiego (1993), zdaje się przy okazji zdradzać w pewnym stopniu swoje nominalistyczne preferencje:

Jest to [realizm inherencyjny] prawdopodobnie niesprzeczne stanowisko ontologiczne - można się zgodzić, że jest możliwe, by rzeczy miały wspólne własności - lecz nie daje się chyba utrzymać w metafizyce - trudno się zgodzić, że faktycznie zdarza się, by 
rzeczy miały wspólne własności. Realizmu abstrakcyjnego nie da się pogodzić z „indywidualizmem ontologicznym”, czyli dość naturalnym przeświadczeniem, że wszystko co istnieje poza umysłem jest jednostkowe (Rojek 2008: 52, moje podkreślenie).

\subsection{UNIWERSALIA DETERMINACYJNE}

- Przyjmuje się, że wszystkie własności przedmiotów (rzeczy) są jednostkowe (indywidualne), i jednocześnie uznaje się uniwersale „za coś nieokreślonego, określanego przez wiele różnych rzeczy” (Rojek 2008: 52).

- Teoria, która koresponduje z koncepcjami formułowanym w dwóch tradycjach: scholastycznej i fenomenologicznej, włącznie z Ingardenem. „Pojęcie powszechnika jako czegoś, co jest dookreślane przez własności i rzeczy, wyraźnie uznawali m.in. św. Tomasz z Akwinu, E. Husserl, R. Ingarden” (Rojek 2008: 52).

- W tym przypadku pierwotną relacją nie jest inherencja, ale determinacja, która zachodzi między określonym i nieokreślonym.

- Przyjmuje się założenie, że żadna róża nie jest po prostu czerwona, gdyż każdy czerwony przedmiot, w tym także róża, ma specyficzny odcień czerwieni lub odmianę tego odcienia, a więc wraz z tymi wszystkimi rodzajami skonkretyzowana jest jako własność czerwień ${ }_{1}$ tej róży. Stąd purpurowy odcień czerwieni, sama czerwień, barwność nie są własnościami tej konkretnej róży. Róża jest czerwona i barwna, lecz czerwień i barwność nie są własnościami róży, tak jak własnością róży jest czerwień ${ }_{1}$, tylko ona inheruje w róży. Czerwień i barwność są natomiast aspektami, które wprawdzie orzeka się o przedmiotach, podobnie jak orzeka się o nich własności, z tą jednak różnicą, że aspekty $\mathrm{w}$ przedmiotach nie inherują.

- Między czerwienią, całkowicie dookreśloną pod względem nasycenia i jasności odcienia, a czerwienią lub barwnością zachodzi relacja określania, czyli determinacji, w zapisie: „y jest dookreśleniem, determinacją $x ”$, czyli „,y ma aspekt $x$ ". I tak czerwień ${ }_{1}$ jest całkowicie (o ile to możliwe) lub najbardziej dookreślona $\mathrm{w}$ stosunku do czerwieni. $\mathrm{W}$ tym szeregu najmniej dookreślona jest barwność, tak więc barwność jest determinowana przez czerwień, a czerwień przez czerwień ${ }_{1}$. Aspekty mogą więc być ogólne, ponieważ wiele rzeczy może być czerwonych i barwnych. Odrzuca się więc wspólne własności na rzecz wspólnych aspektów. Determinacyjne uniwersale jest tym, co jest dookreślane przez różne obiekty (własności i rzeczy). Nie jest ono abstrakcyjne, jako że aspekty nie inherują w przedmiotach. Przyjmuje się jednak, że uniwersalia determinacyjne są składnikami jednostkowych własności, jednak nie w takim 
sensie, w jakim własności są składnikami przedmiotu. Dociera się do nich przez upraszczanie, pomijanie dookreśloności, a nie przez abstrahowanie (przy czym abstrahowanie to nie tylko „myślowe odrywanie”, lecz także pomijanie).

- Jakościowe uniwersale determinacyjne: aspekt „barwność” jest dookreślany przez własności, czyli, mówiąc językiem Ingardena, materię skonkretyzowaną we wszystkich dookreślonych odmianach (czerwonośćc), która inheruje w przedmiocie. Natomiast aspekt „barwność” nie inheruje ani w przedmiocie, ani w tej materii (w czerwoności ${ }_{1}$ ). Substancjalne uniwersale „człowieczeństwo” jest określane przez konkretnego człowieka (rzecz) i wydaje się, że jako aspekt również nie może w niczym inherować, podobnie zresztą jak konkretny byt człowieczy. Człowieczeństwa więc „w” człowieku nie ma.

- Jak zatem należy rozumieć twierdzenia, że jakościowe uniwersale jest jednak składnikiem jednostkowej własności albo że rzeczy, przedmioty indywidualne „mają” ogólne aspekty, uniwersale substancjalne czy też jakościowe, skoro aspekty nie inherują w rzeczy?

- Jak rozumieć można ogólność aspektów: czy tylko w sensie powielalności w różnych indywiduach, czy też jako pewną nieokreśloność i podleganie określeniu? A może na oba te sposoby?

W przypadku jakościowego uniwersale determinującego, np. barwności, jego ogólność polegałaby na tym, że występuje w wielu przypadkach konkretów jako to samo. Jeżeli tożsamość ta polega na identyczności jakościowej, to na gruncie Ingardenowskiej ontologii z tą samą sytuacją mamy do czynienia, gdy mowa o czerwoności $i_{1}$ - nie tylko więc o aspekcie, lecz także o własności można twierdzić, że jest jakościowo, ale nie numerycznie taka sama w różnych indywiduach. Wynika to z dopuszczenia faktu, że istnieją przedmioty identyczne jakościowo, ale numerycznie odmienne, a zasadą indywidualizacji nie jest materialna haecceitas, lecz zasady tej należy szukać w egzystencjalnych uwarunkowaniach, a więc np. posiadaniu własnego istnienia. Gdyby uznać z kolei numeryczną tożsamość aspektu w rożnych konkretach, to na gruncie ontologii Ingardena jest to niemożliwe, zarówno w odniesieniu do materii własności, jak i aspektów. Wykluczają to twierdzenia związane z teorią przedmiotu indywidualnego oraz twierdzenia egzystencjalne. Stanowisko realizmu determinacyjnego zdaje się uznawać materialną zasadę jednostkowienia. Indywidualizujące są pewne materie własności, czy też po prostu własności, natomiast „wspólne” są aspekty dookreślane przez własności. Jedne i drugie orzeka się o przedmiocie, z tą różnicą, że aspekty są poznawczo łatwiej dostępne i swobodnie wyrażalne w języku, co sprzyja częstotliwości ich używania, ale i mylenia ich z własnościami. 
Przyjmując, że zasadą indywidualizacji w takim ujęciu są materie dookreślające aspekty, to po konwersji na ontologię Ingardena w tym miejscu stać mogłyby czyste możliwości, które konkretyzują się jako materie własności. W konsekwencji należałoby przyjąć, że albo jest ich nieskończenie wiele i mamy do czynienia z realizacją ich różnych, niepowtarzalnych konfiguracji, albo same są w jakiś sposób jakościowo swoiste, niepowtarzalne. Ale gdy Ingarden dopuszcza możliwość przyjęcia zasady indywidualizacji jako pewnego specyficznego momentu jakościowego (zwłaszcza w odniesieniu do indywiduów, jakimi są osoby), to, po pierwsze, ten moment jest dla niego raczej jakością postaciową, a po drugie, gdyby już miał się realizować w przedmiocie, to najprawdopodobniej jako moment jego natury konstytutywnej, w formie podmiotu własności.

Aspekt jest składnikiem własności, jednak w przeciwieństwie do własności nie inheruje w przedmiocie ani, co więcej, nie inheruje we własności. Zamiast inherencji pojawia się bowiem relacja determinacji, która - można mniemać - ma charakter ontologiczny. Za własność uznaje się, znów mówiąc językiem Ingardena, materię własności przedmiotu indywidualnego i to ona jako taka jest „W przedmiocie”, jest niesamodzielna wobec przedmiotu, mając jednocześnie składnik (aspekt), który nie jest niesamodzielny i jest nieokreślony. Własność natomiast jest określona i określa swój nieokreślony składnik.

Rysują się tutaj dwie możliwe drogi interpretacyjne: albo jest tak, że aspekt (np. barwność) jest bytem myślnym, co by zresztą korespondowało z sugestią dotyczącą jego prezentacji jako pewnego uproszczenia i brakiem inherencji, albo jest to byt ogólny (nieokreślony), będący składnikiem rzeczy, ewentualnie jakąś niedookreśloną jakością występującą w materialnym momencie własności, stojącą jakby obok jakości, która ją dookreśla. Ta ostatnia sytuacja jest wykluczona, choćby z tego względu, że w ontologii Ingardena, cokolwiek jest zrealizowane w przedmiocie, jest całkowicie indywidualne. Ważniejsze jest jednak to, że jeśli coś jest materią własności, np. „barwa czerwona”, to w przedmiocie jest skonkretyzowane w formie „bycia własnością” i jest przez to właśnie, przez swoją formę, bytowo niesamodzielne względem podmiotu własności. Natomiast w ujęciu ograniczonym do materialności „barwa czerwona” w przedmiocie faktycznie wspólistnieje. Zatem w pierwszym przypadku zarówno barwność (w uproszczeniu), jak i czerwoność inherują w przedmiocie. Są one na innym poziomie niesamodzielne względem siebie, są więc w przedmiocie jakby z konieczności razem współdane, pojawiają się jako jedność „barwa czerwona”, ale żadna $\mathrm{z}$ nich, jako naga materia własności, nie jest niesamodzielna w stosunku do materii podmiotu własności. Pojawiają się wprawdzie w przedmiocie indywidualnym momenty jakościowe w jakiś sposób wzajemnie się określające, dopełniające (jak to Ingarden nazywa), i są one materialnie niesamodzielne, 
nigdy nie jest to jednak niesamodzielność wieloznaczna, o której tutaj jest mowa.

Teoria realizmu determinacyjnego $\mathrm{w}$ zestawieniu $\mathrm{z}$ ontologią Ingardena dokonuje oddzielenia w przedmiocie, przez wyróżnienie aspektów i własności, tego, co właśnie w nim nieoddzielalne, a mianowicie materialnych momentów stojących $w$ formie własności. Innymi słowy, oddziela się na poziomie horyzontalnym to, co na tym poziomie oddzielone być nie może. Taka możliwość co prawda występuje, ale jedynie na poziomie wertykalnym, poziomie idei. Konieczne jest więc przyjęcie kolejnego piętra bytu.

To punkt kluczowy w zestawieniu z przypisywanym Ingardenowi nominalizmem. Ingarden przyjmuje bowiem transcendencję, wyraźne oddzielenie idei i przedmiotów pod nie podpadających. Jest to transcendencja strukturalna, polegająca na samodzielności idei i przedmiotów indywidualnych, na bra$\mathrm{ku}$ związku przyczynowego, związanym z odmiennym sposobem istnienia tych światów, a także na braku partycypacji (w takim znaczeniu, że idee mogłyby występować w przedmiotach indywidualnych lub odwrotnie), na braku możliwości przechodzenia dokładnie tych samych elementów z jednego obszaru w drugi („tych samych” nawet tylko w sensie tożsamości przedmiotów rozumianych jako złożenie formy, materii i sposobu istnienia). Prawie to samo obowiązuje w odniesieniu do najwyższej dziedziny ontologicznej: czystych jakości idealnych. Jednocześnie przedmioty indywidualne podpadają pod idee ze względu na pewne związki materialnych momentów w nich skonkretyzowanych.

Rojek przedstawia argumentację, która niejako pozwala podać w wątpliwość lub nawet zanegować wspomniane materialne uwarunkowania. Otóż czerwień i zieleń - twierdzi - jako idealne jakości się wykluczają, aby więc otrzymać analogiczne twierdzenie o jednostkowych własnościach (czy mówiąc precyzyjniej - o materii własności), trzeba założyć, że czysta jakość (czerwoność, zieloność) odpowiada materii własności (materii czerwieni własności, materii zieleni własności). Konkretyzacja, będąc jedynie przyporządkowaniem, nie daje podstawy dla takiego założenia. Można to uznać za prawdę, choć problematyka konkretyzacji wydaje się bardziej złożona, ważniejsze jednak jest to, że czysta jakość czerwieni i czysta jakość zieleni wcale się nie wykluczają. Wykluczałyby się tylko jako zarazem skonkretyzowane w całości, tj. jako przedmiot indywidualny, natomiast jako czyste jakości nie są do przedmiotów indywidualnych $\mathrm{w}$ ogóle odniesione. Takie odniesienie ma miejsce dopiero wtedy, gdy są one już skonkretyzowane w zawartości idei. Ale nawet i na tym idealnym poziomie wzajemnie się nie wykluczają, istnieją bowiem jako czyste możliwości, przyporządkowane czynnikowi stałemu zmiennej zawartości idei, choć jako czyste możliwości zostają odniesione do przedmiotu indywidualnego, 
a ich „wspólna”, ,jednoczesna” konkretyzacja jest niemożliwa tylko w obrębie całości, jaką jest przedmiot indywidualny.

Jeżeli można więc mówić o jakimkolwiek dookreślaniu np. barwności przez czerwoność, to tylko na poziomie idei, co zresztą w tej ontologii wiąże się również z niesamodzielnością (jedno- lub wieloznaczną) - w takim sensie, że jeżeli $\mathrm{w}$ przedmiocie indywidualnym skonkretyzuje się czerwoność, to w koniecznym połączeniu z barwnością, jako materia własności przedmiotu: „barwa czerwona”. Jednakże stanowiąca tę materię „barwność” nie jest już dookreślana. Oczywiście fakt, że przedmiot czerwony mógłby być niebieski, odsyła do pewnych związków na poziomie zawartości idei, tzn. widocznie zarówno niebieskość, jak i czerwoność są w tej zawartości jedynie czystymi możliwościami, z których jedna się zrealizowała, ale druga także mogła się zrealizować.

Wydaje się, że konfrontacja stanowiska realizmu determinacyjnego z ontologią Ingardena wskazuje na pewną słabość tej koncepcji jako realizmu. Słabość ta ujawnia się mianowicie $\mathrm{w}$ trudności odpowiedzi na pytanie o status bytowy aspektów i w problematyczności określenia związku aspektów z przedmiotem indywidualnym. Z jednej strony aspekty są składnikiem jednostkowej własności, z drugiej - nie inherują w niej ani w przedmiocie. Ponadto są określane przez własności inaczej niż własności określają przedmiot, gdyż własności w nim inherują. Jeśli uznamy zaś, że aspekty są bytem myślnym, intencjonalnym, co wydaje mi się najbardziej rozsądne, staniemy na stanowisku konceptualizmu, a więc jednak pewnej odmiany nominalizmu.

Możemy postawić pytanie: jak to, co ogólne, wspólne wielu, odnosi się do tego, co jednostkowe? Odpowiemy na nie, że dzieje się tak na zasadzie podlegania determinacji. Jeżeli więc to, co ogólne, jest w rzeczy, to jako niedookreślone czyni rzecz sprzeczną, ponieważ może ona posiadać wykluczające się dookreślenia. Jeżeli to, co ogólne, jest w umyśle, to mamy do czynienia z konceptualizmem.

\subsection{UNIWERSALIA KONKRETNE}

- Jednością jest całość dla wielości swoich części, być może rozumiana jako substancja druga Arystotelesa.

- Odwołanie do relacji inherencji ze zmienionym kierunkiem, ponieważ tym, co inheruje w całości, czyli konkretnym uniwersale, są jej elementy konkrety.

W takim ujęciu konieczne jest odrzucenie zarówno Arystotelesowskiego pojęcia substancji pierwszej (jako w niczym nie inherującej), jak i Ingardenow- 
skiej kategorii niesamodzielności bytowej. Relacja konkretu do aspektu, przynajmniej w odniesieniu do uniwersale substancjalnego, opisana w tzw. realizmie determinacyjnym jako dookreślenie, ulega wzmocnieniu i staje się inherencją, ponieważ np. wszystkie zwierzęta mogą inherować w jedynym bycie stanowiącym ich konkretyzację - w konkretnej zwierzęcości.

- Ostateczną konkretyzacją wszystkiego jest wszechogarniający konkretny powszechnik - wszechogarniający konkretny byt. Wszystkie byty, abstrakcyjne uniwersalia, abstrakcyjne partykularia, w końcu substancje pierwsze, zawierają się w substancjach drugich w rozumieniu Arystotelesowskim. Dany rodzaj należy zatem rozumieć jako jednostkowe przypadki, w których nie zawiera się uniwersale, lecz które same zawierają się w uniwersale.

Aby odnieść stanowisko konkretnego uniwersale do ontologii Ingardena, należałoby omówić bytową zależność, a także zaangażować wypracowaną przez Ingardena aparaturę związaną z teorią całości i części, odnieść się do kategorii przedmiotów wyższego rzędu, całości sumatywnych, systemów względnie izolowanych oraz dziedzin przedmiotowych, dziedzin bytowych i klas. Jednak także bez tego można założyć, że nie są to koncepcje zbieżne.

\section{UWAGI KOŃCOWE}

W podsumowaniu pragnę zwrócić uwagę na kilka kwestii:

- Rzetelna krytyka ontologii Ingardena powinna uwzględniać wszystkie wyróżnione przez niego piętra bytowe (triadę: czyste jakości idealne, idee, przedmioty indywidualne) oraz związki egzystencjalne, formalne i materialne, gdyż w przeciwnym razie może ona nosić znamiona krytyki pozornej.

- Podobnie rzecz się ma z prezentowaną wykładnią poglądów Platona: trudno nie ulec wrażeniu, że wybrane interpretacje platońskiego świata idei oraz partycypacji są w dużej mierze krzywdzące.

- Wymóg dla bycia „prawdziwym” uniwersale, przyjęty w punkcie wyjścia, a więc rozumienie uniwersale jako jedności „w" wielości, jest zbyt mocny; wydaje się, że nie został on również spełniony przez stanowiska, które z założenia miały go spełnić (realizm immanentny).

- W tej perspektywie stanowisko skrajnego realizmu przestaje jawić się jako wątpliwy realizm. 
- Bogata ontologia pozwala na analizy uwzględniające różnorodne rozumienia uniwersale (własności, jakości, przedmioty ogólne, struktury, prawa) oraz ich ewentualne połączenia, a ponadto pozwala badać konsekwencje egzystencjalne, tj. wynikające z przyjmowania różnych sposobów istnienia.

\section{BIBLIOGRAFIA}

Armstrong D. M. (1978), Nominalism and Realism: Universals and Scientific Realism, vol. 1, Cambridge: Cambridge University Press.

Armstrong D. M. (1989), Universals: An Opinionated Introduction, London: Westview Press.

Barska K. (2013), Konkretyzacja - odpowiedniość czy uczestnictwo? [w:] Świadomość, świat, wartość. Prace ofiarowane Profesorowi Andrzejowi Póttawskiemu w 9o. rocznice urodzin, D. Leszczyński, M. Rosiak (red.) Wrocław: Oficyna Wydawnicza PFF, 279-290.

Barska K. (2014a), Negatywne stany rzeczy $w$ ontologii Romana Ingardena, „Filozofia Nauki" 22(4) [88], 131-148.

Barska K. (2014b), Analiza typów bytowej niesamodzielności w ontologii Romana Ingardena, „Filo-Sofija” 14(25), 271-282.

Bergmann G. (1964), The Ontology of Edmund Husserl [w:] Logic and Reality, Madison: The University of Wisconsin Press, 193-224.

Bocheński J. M. (1993), Zagadnienie powszechników [w:] Logika i filozofia. Wybór pism, Warszawa: Wydawnictwo Naukowe PWN, 79-105.

Campbell K., Franklin J., Ehring D. (2019), Donald Cary Williams [w:] The Stanford Encyclopedia of Philosophy (Fall 2019 Edition), E. N. Zalta (ed.), https://stanford.io/3pC7ufZ.

Chrudzimski A. (2010), Composed Objects, Internal Relations, and Purely Intentional Negativity: Ingarden's Theory of States of Affairs, „Polish Journal of Philosophy” 2(4). https://doi.org/10.5840/pjphil20104217

Chrudzimski A. (2011), Realistyczne teorie uniwersaliów [w:] Przewodnik po metafizyce, S. T. Kołodziejczyk (red.), Kraków: WAM, 127-159.

Dębiński B. (1997), Teoria idei. Ewolucja myśli Platońskiej, Katowice: Wydawnictwo UŚ.

Gadamer H. G. (1985), Platons Ungeschriebene Dialektik [w:] Gesammelte Werke, Bd. 6: Griechische Philosophie, Tübingen: Mohr Siebeck, 129-153.

Gałecki J. (1964), Istota istnienia [w:] Szkice filozoficzne. Romanowi Ingardenowi w darze, Z. Żarnecka (red.) Warszawa-Kraków: Państwowe Wydawnictwo Naukowe, 9-70.

Grygianiec M. (2000), Leśniewski przeciw powszechnikom, „Filozofia Nauki” 8(3-4) [31-32], 109-125.

Grygianiec M. (2001), Kotarbiński przeciw uniwersaliom, „Przegląd Filozoficzny - Nowa Seria" 8(3) [39], 95-114.

Hartmann N. (1966), Möglichkeit und Wirklichkeit, Berlin-New York: de Gruyter. https:// doi.org/10.1515/9783110823882

Ingarden R. (1961), Spór o istnienie świata, t. 2, tłum. D. Gierulanka, Warszawa: Państwowe Wydawnictwo Naukowe.

Ingarden R. (1987), Spór o istnienie świata, wyd. III, tłum. D. Gierulanka, Warszawa: Państwowe Wydawnictwo Naukowe. 
Johansson I. (2009), Proof of the Existence of Universals - and Roman Ingarden's Ontology, „Metaphysica” 10, 65-87. https://doi.org/10.1007/s12133-008-0040-o

Judycki S. (2020), Epistemologia, t. II, Poznań-Warszawa: Wydawnictwo „W drodze”.

Kaczmarek J. (2006), Uniwersalia a przedmioty ogólne, „Acta Universitatis Lodziensis. Folia Philosophica" 17, 39-59.

Loux M. J. (2006), Metaphysics: A Contemporary Introduction, London-New York: Routledge. https://doi.org/10.4324/9780203968871

Moreland J. P. (2001), Universals, Chesham: Acumen. https://doi.org/10.1017/ UPO97818 44653270

Nowak A. (2013), Historia i kres awersji. O ewolucji i znaczeniu Peirce'owskiej krytyki platonizmu [w:] Świadomość, świat, wartość. Prace ofiarowane Profesorowi Andrzejowi Póttawskiemu w 9o. rocznicę urodzin. D. Leszczyński, M. Rosiak (red.) Wrocław: Oficyna Wydawnicza PFF, 253-277.

Oliver A. (1996), The Metaphysics of Properties, „Mind” 105(417), 1-80. https://doi.org/ 10.1093/mind/105.417.1

Orilia F., Paolini Paoletti M. (2020), Properties [w:] The Stanford Encyclopedia of Philosophy (Winter 2020 Edition), E. N. Zalta (ed.), https://stanford.io/2Zqn9UQ.

Penrose R. (2007), Droga do rzeczywistości. Wyczerpujący przewodnik po prawach rzqdzacych wszechświatem, tłum. J. Przystawa, Warszawa: Prószyński i S-ka.

Piwowarczyk M. (2014), Krytyka realizmu immanentnego $w$ kwestii uniwersaliów - argument z oddzielenia, „Filozofia Nauki” 22(4) [88], 109-130.

Piwowarczyk M. (2020), Platonizm a spór o uniwersalia. W związu z książka Pawła Rojka Tropy i uniwersalia, „Filozofia Nauki” 28(2) [110], 113-133. https://doi.org/10.14394/ filnau.2020.0012

Platon (1959), Menon, tłum. W. Witwicki, Warszawa: Państwowe Wydawnictwo Naukowe.

Platon (2010), Państwo, tłum. W. Witwicki, Warszawa: Wydawnictwo Naukowe PWN.

Platon (1961), Parmenides, tłum. W. Witwicki, Warszawa: Państwowe Wydawnictwo Naukowe.

Rojek P. (2008), Trzy pojęcia uniwersaliów, „Kwartalnik Filozoficzny” 36(3): 45-61.

Rojek P. (2019), Tropy $i$ uniwersalia. Badania ontologiczne, Warszawa: Wydawnictwo Naukowe Semper.

Ross D. (1951), Plato's Theory of Ideas, Oxford: Oxford University Press.

Simons P. M. (1995), Kategorie i sposoby istnienia [w:] W kręgu filozofii Romana Ingardena, W. Stróżewski, A. Węgrzecki (red.),Warszawa: Wydawnictwo Naukowe PWN, 63-77.

Szymura J. (2011), Nominalizm [w:] Przewodnik po metafizyce, S. T. Kołodziejczyk (red.), Kraków: WAM, 161-210.

Widomski J. (2003), Platońska teoria partycypacji a problem konkretyzacji $w$ filozofii Romana Ingardena [w:] Wielkość i piękno filozofii, J. Lipiec (red.), Kraków: Wydawnictwo Collegium Columbinum.

Williams D. C. (1997), The Elements of Being: I [w:] Properties, D. H. Mellor, A. Oliver (eds.), Oxford: Oxford University Press, 112-124. 